\title{
Small-molecule inhibition of BRD4 as a new potent approach to eliminate leukemic stem- and progenitor cells in acute myeloid leukemia (AML)
}

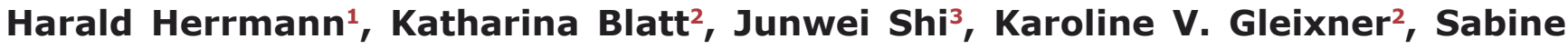 \\ Cerny-Reiterer ${ }^{1}$, Leonhard Müllauer ${ }^{4}$, Christopher R. Vakoc ${ }^{3}$, Wolfgang R. Sperr ${ }^{1,2}$, \\ Hans-Peter Horny ${ }^{6}$, James E. Bradner ${ }^{5}$, Johannes Zuber ${ }^{3,7}$, Peter Valent ${ }^{1,2}$ \\ ${ }^{1}$ Ludwig Boltzmann Cluster Oncology, Vienna, Austria; \\ ${ }^{2}$ Department of Internal Medicine I, Division of Hematology and Hemostaseology, Medical University of Vienna, Austria; \\ ${ }^{3}$ Cold Spring Harbor Laboratory, Cold Spring Harbor, NY, USA; \\ ${ }^{4}$ Department of Pathology, Medical University of Vienna, Austria; \\ ${ }^{5}$ Department of Medical Oncology, Dana-Farber Cancer Institute, Harvard Medical School, Boston, MA, USA; \\ ${ }^{6}$ Institute of Pathology, Ludwig-Maximilians-University, Munich, Germany; and \\ ${ }^{7}$ Research Institute of Molecular Pathology (IMP), Vienna, Austria. \\ Correspondence to: Peter Valent, email: peter.valent@meduniwien.ac.at
}

Keywords: AML, leukemic stem cells, BRD4, JQ1, targeted therapy

Received: November 02, 2012, Accepted: November 26, 2012, Published: November 27, 2012

Copyright: (C) Herrmann et al. This is an open-access article distributed under the terms of the Creative Commons Attribution License, which permits unrestricted use, distribution, and reproduction in any medium, provided the original author and source are credited.

ABSTRACT:

Acute myeloid leukemia (AML) is a life-threatening stem cell disease characterized by uncontrolled proliferation and accumulation of myeloblasts. Using an advanced RNAi screen-approach in an AML mouse model we have recently identified the epigenetic 'reader' BRD4 as a promising target in AML. In the current study, we asked whether inhibition of BRD4 by a small-molecule inhibitor, JQ1, leads to growthinhibition and apoptosis in primary human AML stem- and progenitor cells. Primary cell samples were obtained from 37 patients with freshly diagnosed AML $(n=23)$ or refractory AML $(n=14)$. BRD4 was found to be expressed at the mRNA and protein level in unfractionated AML cells as well as in highly enriched CD34+/CD38- and $\mathrm{CD}^{2} 4^{+} / \mathrm{CD} 38^{+}$stem- and progenitor cells in all patients examined. In unfractionated leukemic cells, submicromolar concentrations of JQ1 induced major growth-inhibitory effects $\left(\mathrm{IC}_{50} 0.05-0.5 \mu \mathrm{M}\right)$ in most samples, including cells derived from relapsed or refractory patients. In addition, JQ1 was found to induce apoptosis in CD34+/CD38and $\mathrm{CD}_{34}{ }^{+} / \mathrm{CD}_{3} 8^{+}$stem- and progenitor cells in all donors examined as evidenced by combined surface/Annexin-V staining. Moreover, we were able to show that JQ1 synergizes with ARA-C in inducing growth inhibition in AML cells. Together, the BRD4targeting drug JQ1 exerts major anti-leukemic effects in a broad range of human AML subtypes, including relapsed and refractory patients and all relevant stem- and progenitor cell compartments, including $\mathrm{CD} 34^{+} / \mathrm{CD} 38^{-}$and $\mathrm{CD} 34^{+} / \mathrm{CD} 38^{+} \mathrm{AML}$ cells. These results characterize BRD4-inhibition as a promising new therapeutic approach in AML which should be further investigated in clinical trials.

\section{INTRODUCTION}

Acute myeloid leukemia (AML) is a stem cellderived hematopoietic malignancy characterized by uncontrolled proliferation and accumulation of myeloblasts in the bone marrow (BM), blood, and other organs. The clinical course and prognosis in AML vary, depending on age, the biology and category of the disease, cytogenetic features and number and types of deregulated genes [1-6]. In a subset of patients, cytogenetic and/ 
or molecular features are indicative of a more favorable prognosis. When treated with repeated chemotherapy cycles or/and hematopoietic stem cell transplantation (SCT), these patients have a relatively good prognosis and many of them enter long-term disease-free survival [1-8]. However, not all patients with AML have a suitable donor or are eligible for SCT. In other patients, the response to chemotherapy is poor or short-lived. For AML patients who relapse or have resistant disease, therapeutic options are limited. Current research is seeking novel drug targets and novel, more potent, drugs for these poor-risk patients [9-13].

One key event in oncogenic transformation in AML is the corruption of myeloid cell-fate programs resulting in the generation of aberrantly self-renewing cells, the so-called leukemic stem cells (LSC), which maintain and propagate the disease and are often resistant to conventional chemotherapy [14-16]. Notably, in AML and other myeloid leukemias, the malignant clone is organized hierarchically with more mature cells programmed to undergo apoptosis after a variable number of cell divisions, and immature primitive cells that have self-renewing and leukemia-propagating capacity [14-18]. Although the exact phenotype of LSC in AML remains uncertain, several studies have suggested that in various AML subtypes, the NOD/SCID mouse-repopulating LSC reside within a $\mathrm{CD} 34^{+} / \mathrm{CD} 38^{-}$fraction of the leukemic clone [16-21]. Other studies have shown that NSG mouse-repopulating AML stem cells reside in both the $\mathrm{CD} 4^{+} / \mathrm{CD} 38^{+}$and the $\mathrm{CD} 34^{+} / \mathrm{CD} 38^{-}$fraction of $\mathrm{AML}$ cells, or even in $\mathrm{CD}^{-} 4^{-}$subfractions of the clone [22,23]. Clinically, the LSC concept is of great importance and may have prognostic and therapeutic implications [2432]. Notably, strategies aimed at terminating aberrant self-renewal or survival of LSC are considered key to the development of more effective therapies [26-32].

In an effort to systematically probe genes involved in chromatin regulation as potential therapeutic targets, we have recently developed an unbiased screen approach, combining AML mouse models and new in vivo RNAi technologies. Through this approach we were able to identify the epigenetic 'reader' Bromodomain-containing 4 Protein (BRD4) as a new potential target in AML [33]. Inhibition of BRD4 using BRD4-specific RNAi or JQ1, a BET bromodomain inhibitor that blocks BRD4-binding to acetylated histones, showed profound antileukemic effects in AML mouse models as well as in various human AML cell lines and in primary leukemic cells obtained from AML patients [33].

In the present study, we extended these analyses to various subtypes of AML as well as to AML LSC. The specific aim of our study was to evaluate BRD4-inhibition as a potential therapeutic approach to target and eliminate LSC in AML. To address this question, we analyzed the effects of JQ1 on primary neoplastic stem- and progenitor cells obtained from patients with freshly diagnosed or refractory AML. In addition, we asked whether JQ1 would synergize with conventional cytostatic drugs to produce synergistic anti-leukemic effects in AML.

\section{RESULTS}

\section{BRD4 is expressed in AML cells including CD34 ${ }^{+}$ stem $^{-}$and progenitor cells}

As assessed by qPCR analysis, BRD4 mRNA was found to be expressed in highly enriched sorted $\mathrm{CD}^{+} 4^{+}$ $\mathrm{CD} 8^{+} \mathrm{AML}$ progenitor cells and $\mathrm{CD} 34^{+} / \mathrm{CD} 38^{-}$stem cells (Figure 1A). In addition, all AML cell lines examined (HL60, U937, KG1, MV4-11, MOLM-13) were found to express BRD4 mRNA (not shown). Expression of the BRD4 protein in AML cells was examined by ICC and IHC. As assessed by ICC, BRD4 was found to be expressed in primary AML cells (blasts) in all donors without negative subpopulations (Figure 1B). More importantly, we found that in all donors examined, the $\mathrm{CD} 34^{+} / \mathrm{CD} 38^{+}$and the $\mathrm{CD} 34^{+} / \mathrm{CD} 38^{-}$stem- and progenitor cells express the BRD4 antigen without negative subpopulations (Figure 1B). No differences in BRD4 expression were seen when comparing different FAB or WHO subtypes of AML. In addition, all AML cell lines tested were found to stain positive for BRD4 (Figure 1C). BRD4 was found to be expressed in both the cytoplasmic compartment and nuclear compartment of leukemic cells in all patients and all cell lines tested (Figure 1B and 1C), and the same was found when normal BM cells or cord blood cells were analyzed (not shown). Preincubation of the anti-BRD4 antibody with a specific blocking peptide resulted in a negative stain (Figure 1C). Corresponding results were obtained by IHC. Again, BRD4 was found to be expressed in the nuclear and cytoplasmic compartment of leukemic cells in all donors and all AML variants tested (Figure 1D). In the normal BM, BRD4 was also expressed in myeloid progenitor cells as well as in megakaryocytes. However, compared to the leukemic marrow, BRD4 expression appeared to be more restricted to the nuclear compartment of myeloid cells. Table 1 shows the distribution of BRD4 in the various cellular compartments in AML and in control BM sections. Together, our data show that BRD4 is expressed in both the cytoplasm and in the nuclei of AML blasts and AML LSC.

\section{The BRD4-targeting drug JQ1 inhibits proliferation of leukemic cells in freshly diagnosed and relapsed or refractory AML}

Confirming our previous data [33] the BET bromodomain inhibitor JQ1 was found to block ${ }^{3} \mathrm{H}$-thymidine uptake and thus proliferation in 
A

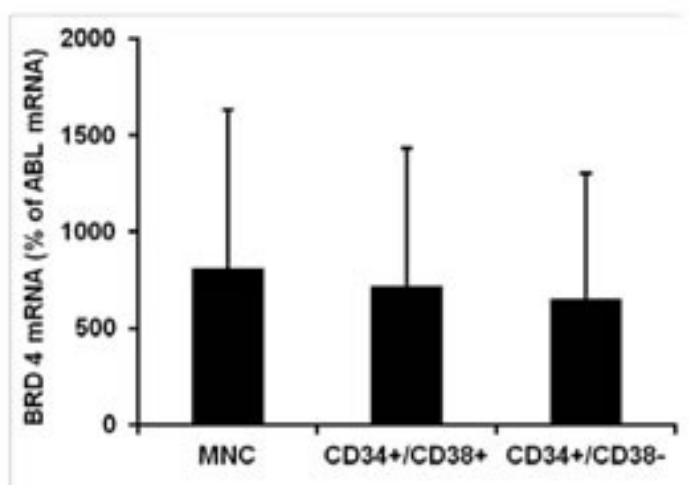

C
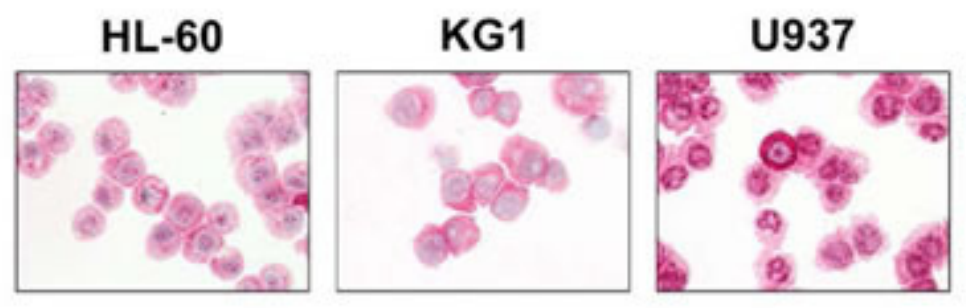

MOLM13

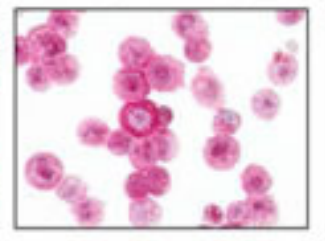

\section{MV4-11}

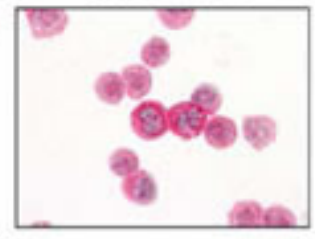

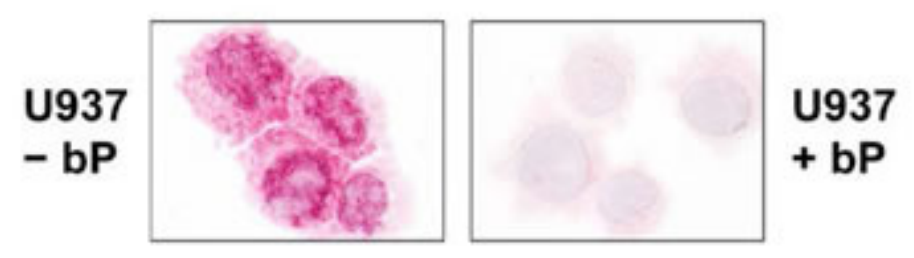

D
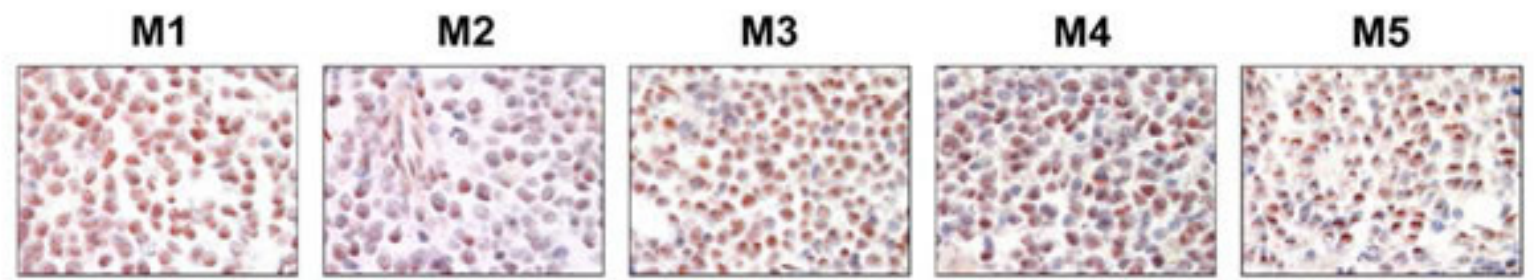

Figure 1: Expression of BRD4 in leukemic cells in acute myeloid leukemia (AML). A: Highly purified (sorted) $\mathrm{CD}_{34}+/$ $\mathrm{CD} 38^{-}$and $\mathrm{CD}^{+} 4^{+} / \mathrm{CD} 38^{+}$stem and progenitor cells of 9 patients with AML were subjected to RNA isolation and qPCR as described in the text. BRD4 mRNA levels are shown as percent of ABL mRNA levels. Results are expressed as mean \pm S.D. of 9 donors. B: Detection of the BRD4 protein in the cytoplasm and in the nuclei of CD34 $/ \mathrm{CD} 38^{-}$(left panels) and CD $34^{+} / \mathrm{CD} 38^{+}$stem- and progenitor cells (middle panels) purified from mononuclear cells (MNC) by cell sorting (purity $>98 \%$ ) in 2 patients with AML (numbers refer to patients shown in Table 3 ). Immunocytochemistry was performed on cytospin slides using an anti-BRD4 antibody. The staining reaction in the total (non-sorted) MNC fraction is also shown (right panels). C: Expression of BRD4 in AML cell lines (HL60, KG-1, U937, MOLM13, MV4-11) as determined by indirect immunocytochemistry using an anti-BRD4 antibody. In the lower panel, the anti-BRD4 antibody was preincubated with control medium (-bP; lower left panel) or with a BRD4-specific blocking peptide (+bP, lower right panel) before being applied on U937 cells. D: Immunohistochemical detection of BRD4 in AML cells in bone marrow sections obtained from patients with AML (FAB categories M1, M2, M3, M4, and M5). Again, BRD4 was detected in the cytoplasm as well as in the nuclei of AML blasts. Indirect immunohistochemistry was performed using an anti-BRD4 antibody. 
Table 1: Cellular distribution of BRD4 in bone marrow (BM) sections in AML and controls

\begin{tabular}{|l|c|c|c|c|c|c|}
\hline & \multicolumn{3}{|c|}{ cytoplasmic BRD4 staining } & \multicolumn{2}{c|}{ nuclear BRD4 staining } \\
\hline Cell type & $\begin{array}{c}\text { normal/ } \\
\text { reactive BM }\end{array}$ & $\begin{array}{c}\text { primary } \\
\text { AML }\end{array}$ & $\begin{array}{c}\text { relapsed/ } \\
\text { refractory } \\
\text { AML }\end{array}$ & $\begin{array}{c}\text { normal/ } \\
\text { reactive BM }\end{array}$ & $\begin{array}{c}\text { primary } \\
\text { AML }\end{array}$ & $\begin{array}{c}\text { relapsed/ } \\
\text { refractory } \\
\text { AML }\end{array}$ \\
\hline Megakaryocytes & $+/-$ & $+/-$ & + & + & + & + \\
\hline Myeloblasts & n.d. & $+/-$ & + & + & + & + \\
\hline $\begin{array}{l}\text { Myeloid } \\
\text { progenitor cells }\end{array}$ & $+/-$ & + & $+/-$ & $+/-$ & $+/-$ & + \\
\hline $\begin{array}{l}\text { Neutrophil } \\
\text { granulocytes }\end{array}$ & $+/-$ & $+/-$ & $+/-$ & $+/-$ & $+/-$ & $+/-$ \\
\hline $\begin{array}{l}\text { Eosinophil } \\
\text { granulocytes }\end{array}$ & - & $+/-$ & - & - & & - \\
\hline Erythroid cells & - & - & $+/-$ & $+/-$ & $+/-$ & + \\
\hline Lymphocytes & n.d. & $+/-$ & + & + \\
\hline
\end{tabular}

Bone marrow sections were stained with an anti-BRD4 antibody as described in the text.

Score: -, negative; +/-, weakly positive or positive in a smaller subset of cells; +, mostly positive.

Abbreviations: BM, bone marrow; AML, acute myeloid leukemia; n.d., not determined.

unfractionated primary AML blasts. In particular, JQ1 was found to inhibit the proliferation of leukemic cells in 27/28 AML patients tested, with reasonable $\mathrm{IC}_{50}$ values $(<1 \mu \mathrm{M})$ (Table 2). Anti-leukemic effects of JQ1 were seen in all patients with primary, untreated AML $(n=18)$, and in 9/10 patients $(90 \%)$ with relapsed or refractory AML (Table 2). In the responding patients, $\mathrm{IC}_{50}$ values ranged between 20 and $450 \mathrm{nM}$ (median: $100 \mathrm{nM}$ ) without major differences when comparing freshly diagnosed AML patients with relapsed or refractory AML (Table 2, Figure 2A). In normal BM samples $(n=3)$, JQ1 also produced growth inhibition, but the $\mathrm{IC}_{50}$ values were higher compared to that found in AML cells ( $\mathrm{IC}_{50}: 100-500 \mathrm{nM}$, median: 250 $\mathrm{nM})$.

\section{JQ1 induces apoptosis in primary AML cells}

In a next step, we examined the mechanism(s) of JQ1-induced growth inhibition in AML cells. In these experiments, JQ1 was found to induce apoptosis in primary AML cells in all samples tested, including cells derived from freshly diagnosed or relapsed patients. Induction of apoptosis was measured by light microscopy (Figure 3A) as well as by caspase 3 staining and flow cytometry (Figure 3B). JQ1 also produced apoptosis in all AML cell lines tested confirming our previous data (not shown) [33].
A

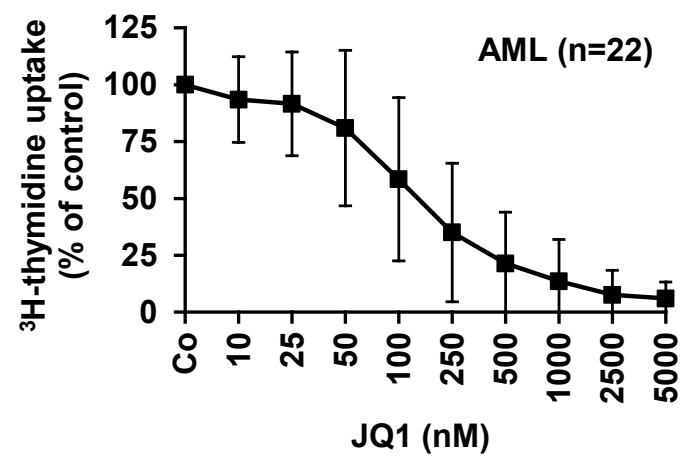

B

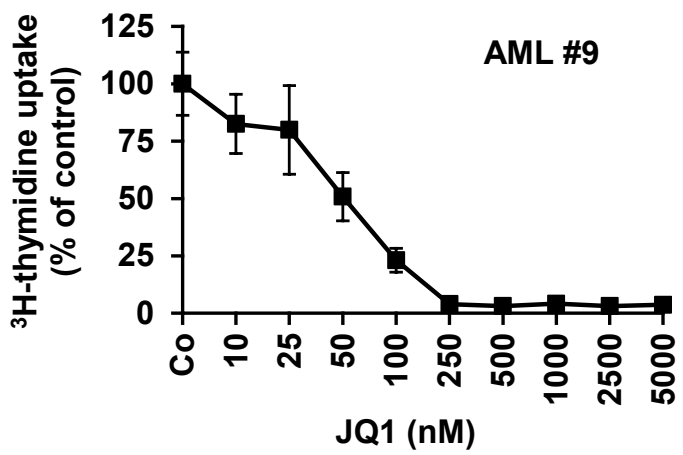

Figure 2: Effects of JQ1 on proliferation of AML cells. A: Isolated AML blasts of 22 patients with AML were incubated in control medium (Co) or medium containing various concentrations of JQ1, as indicated, at $37^{\circ} \mathrm{C}$ and $5 \% \mathrm{CO}_{2}$ for 48 hours. Then, uptake of ${ }^{3} \mathrm{H}$-thymidine was measured. Results are expressed as percent of medium control and show the mean \pm S.D. values from these 22 patients. B: AML blasts from patient \#9 (in Table 3) were incubated in control medium or medium containing various concentrations of JQ1 (as indicated) at $37^{\circ} \mathrm{C}$ and $5 \% \mathrm{CO}_{2}$ for 48 hours. Then, uptake of ${ }^{3} \mathrm{H}$-thymidine was measured. Results are expressed as percent of control and show the mean \pm S.D. of triplicates. 
Table2: Effects of JQ1 on proliferation of primary leukemic cells

\begin{tabular}{|c|c|c|c|c|c|}
\hline \multirow[b]{2}{*}{ AML No\# } & \multirow[b]{2}{*}{ FAB } & \multirow[b]{2}{*}{ WHO } & \multirow[b]{2}{*}{ Source PB/BM } & \multicolumn{2}{|c|}{${ }^{3} \mathrm{H}$-thymidine-uptake } \\
\hline & & & & $\begin{array}{l}+ \text { cytokines** }^{*} \\
\text { IC }_{50}(\mathrm{nM})\end{array}$ & $\begin{array}{c}\text {-cytokines } \\
\mathrm{IC}_{50}(\mathrm{nM})\end{array}$ \\
\hline $1^{*}$ & M1 & AML with $\mathrm{t}(9 ; 11)$ & PB & 280 & n.t. \\
\hline 2 & M5 & AML monoblastic & $\mathrm{BM}$ & 90 & 70 \\
\hline 3 & M5 & AML with $(9 ; 11) / \mathrm{NPM} 1 \mathrm{~m}$ & $\mathrm{BM}$ & 160 & 240 \\
\hline 4 & M4 & AML with mutated NPM1 & PB & 1,030 & 420 \\
\hline 5 & M1 & AML with mutated NPM1 & $\mathrm{BM}$ & 420 & n.t. \\
\hline 6 & M4 & AML myelomonocytic & $\mathrm{BM}$ & 1,420 & 140 \\
\hline 7 & M1 & AML with myelodysplasia & $\mathrm{BM}$ & 40 & n.t. \\
\hline $8^{*}$ & M5 & AML with myelodysplasia & $\mathrm{PB}$ & 40 & 40 \\
\hline 9 & M5 & AML monoblastic & $\mathrm{BM}$ & 50 & 50 \\
\hline 10 & M4 & AML with inv16 & $\mathrm{BM}$ & 150 & 70 \\
\hline 11 & M2 & AML with $\mathrm{t}(8 ; 21)$ & $\mathrm{BM}$ & 40 & n.t. \\
\hline 12 & M2 & AML with $\mathrm{t}(8 ; 21)$ & $\mathrm{BM}$ & 60 & n.t. \\
\hline 13 & RAEB-T & AML with myelodysplasia & $\mathrm{BM}$ & n.t. & 60 \\
\hline 14 & M1 & AML without maturation & $\mathrm{BM}$ & n.t. & 150 \\
\hline $15^{*}$ & sec. & AML with myelodysplasia & PB & n.t. & 1,800 \\
\hline $16^{*}$ & M6a & acute erythroid leukemia & PB & 40 & n.t. \\
\hline $17^{*}$ & M4 & AML myelomonocytic & $\mathrm{BM}$ & n.t. & 280 \\
\hline 19 & M4 & Therapy related AML & $\mathrm{BM}$ & n.t. & 250 \\
\hline 20 & M1 & AML with mutated NPM1 & BM & n.t. & 440 \\
\hline $22 *$ & sec. & AML with myelodysplasia & $\mathrm{BM}$ & n.t. & 70 \\
\hline $23 *$ & sec. & AML with myelodysplasia & PB & n.t. & 85 \\
\hline $24 *$ & M4 & AML myelomonocytic & $\mathrm{BM}$ & n.t. & 230 \\
\hline $25^{*}$ & sec. & AML with myelodysplasia & $\mathrm{BM}$ & n.t. & 90 \\
\hline 26 & M4 & AML with myelodysplasia & $\mathrm{BM}$ & n.t. & 260 \\
\hline $27 *$ & M4 & AML monocytic & $\mathrm{BM}$ & n.t. & 20 \\
\hline 28 & M1 & AML with mutated NPM1 & $\mathrm{BM}$ & n.t. & 80 \\
\hline 29 & sec. & AML with myelodysplasia & $\mathrm{BM}$ & n.t. & 30 \\
\hline 30 & M5 & AML with mutated NPM1 & $\mathrm{BM}$ & n.t. & 110 \\
\hline
\end{tabular}

*These patients were analyzed at relapse or persistence of blasts. ${ }^{* *}$ Cells were cultured in stem cell factor (SCF), interleukin-3 (IL-3) and granulocyte colony-stimulating factor (G-CSF) (each $100 \mathrm{ng} / \mathrm{ml}$ ). Abbreviations: AML, acute myeloid leukemia; FAB, French-American-British cooperative study group; PB, peripheral blood; BM, bone marrow; n.t., not tested. 


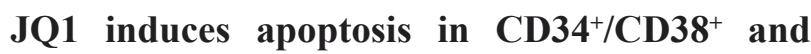
$\mathrm{CD34}^{+} / \mathrm{CD38}^{-}$leukemic stem ${ }^{-}$and progenitor cells in freshly diagnosed AML and relapsed/refractory AML

In a next step, we examined the effects of JQ1 on survival of leukemic stem- and progenitor cells derived from our AML patients. As shown in Figure 3C, JQ1 induced apoptosis in $\mathrm{CD} 34^{+} / \mathrm{CD} 38^{+}$as well as $\mathrm{CD} 34^{+} /$ CD38- stem and progenitor cells in all samples and all donors tested, including patients with relapsed or refractory AML, and without major differences when comparing FAB or WHO subtypes.

\section{JQ1 synergizes with ARA-C in producing growth inhibition in AML cells}

Since JQ1 and other (similar) BET bromodomain inhibitors are considered to be used in clinical trials in AML patients in combination with conventional cytostatic drugs like ARA-C, we asked whether JQ1 and ARA-C would produce cooperative or even synergistic growth-

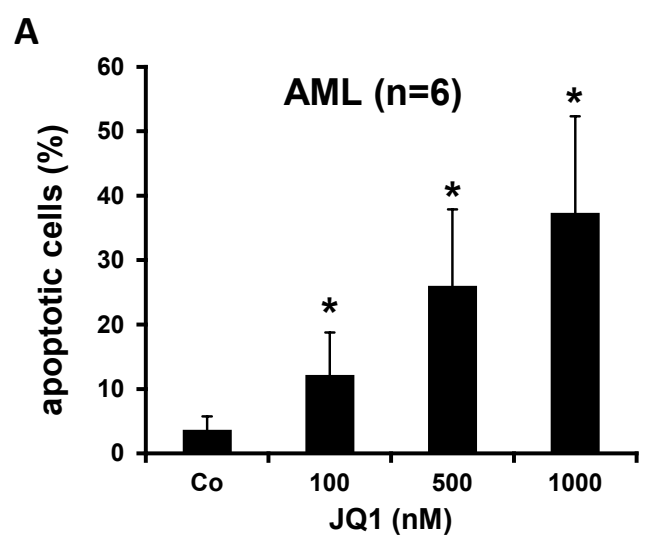

B

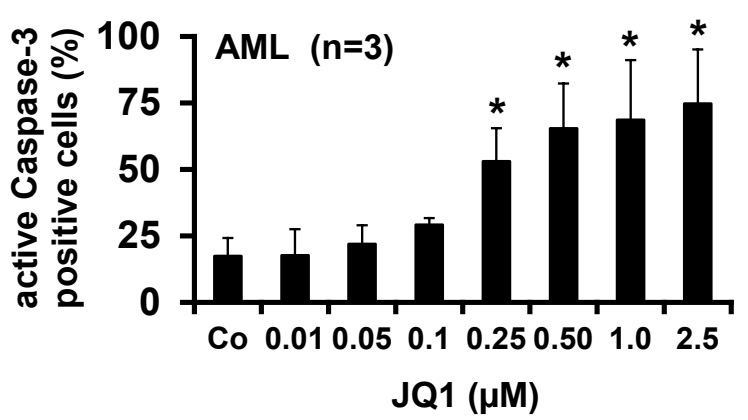

inhibitory effects on AML cells. For these experiments, the AML cell lines HL60 and KG1 were employed. As visible in Figure 4, JQ1 was found to exert strong synergistic antileukemic effects when combined with ARA-C in both cell lines (Figure 4). These data suggest that drug combinations employing conventional cytostatic drugs, like ARA-C and a BET bromodomain inhibitor, may produce synergistic antileukemic effects in AML cells.

\section{DISCUSSION}

Based on their self-renewal and disease-propagating capacity, leukemic stem- and progenitor cells represent an attractive therapeutic target in AML [26-32]. Notably, AML LSC are considered a relevant source of relapsing disease and exhibit intrinsic as well as acquired resistance [28-32]. Therefore, considerable efforts have been made to understand the mechanisms of LSC resistance, and to identify new drug targets that play an important role in survival, self renewal, and proliferation of AML LSC. However, so far, little is known about the expression of molecular targets in AML LSC and about effects of various targeted drugs [25-28]. We have recently shown that the epigenetic reader BRD4 is a novel promising target in AML [33]. In the present study, we have extended these analyses and show that AML LSC express BRD4, and that the BRD4-targeting drug JQ1 induces growth inhibition and apoptosis in these cells, which may have
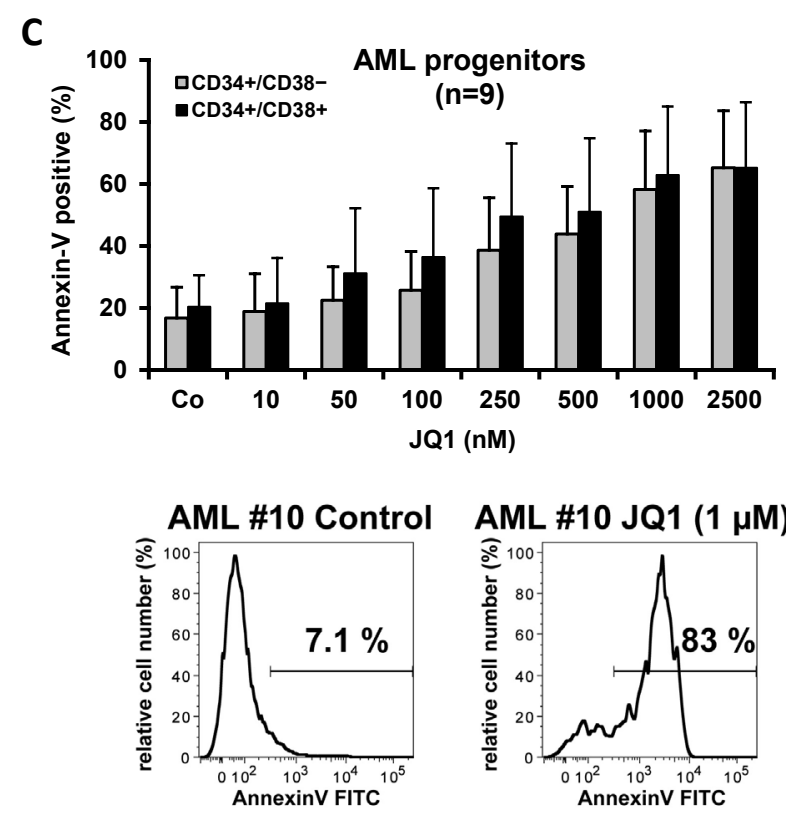

Figure 3: Effects of JQ1 on survival of AML stem- and progenitor cells. Primary AML cells were incubated in the absence (Co) or presence of JQ-1 (10-2,500 nM) for 48 hours. Then, the percentage of apoptotic cells was determined on Wright-Giemsa-stained cytospin preparations (A), and the percentage of active Caspase-3-positive cells was determined by flow cytometry (B). Results represent the mean \pm S.D. from 6 patients (A) or 3 patients (B). Asterisk: $\mathrm{p}<0.05$ compared to medium control. C: Upper panel: Primary AML cells $(\mathrm{n}=9)$ were cultured in control medium $(\mathrm{Co})$ or JQ1 $(10-2,500 \mathrm{nM})$ at $37^{\circ} \mathrm{C}$ for 48 hours. $\mathrm{CD}^{+} 4^{+} / \mathrm{CD} 38^{+} \mathrm{AML}$ progenitor cells and $\mathrm{CD} 34^{+} /$ CD38- AML stem cells were examined by combined staining for surface antigens and Annexin-V-FITC. Apoptosis was expressed as percent Annexin-V-positive cells. Results in the upper panel represent the mean \pm S.D. from 9 donors. The lower panel shows an example of Annexin-V expression in $\mathrm{CD} 34^{+} / \mathrm{CD} 38^{-}$AML stem cells after exposure to control medium or JQ1 (1 $\left.\mu \mathrm{M}\right)$ for 48 hours in patient \#10. 
Table 3: Patients' Characteristics

\begin{tabular}{|c|c|c|c|c|c|c|c|c|c|}
\hline & & & & Diagnosis & & $\%$ Bla & tCells & & \\
\hline No\# & $\mathbf{F} / \mathbf{M}$ & $\begin{array}{l}\text { Age } \\
\text { Yrs }\end{array}$ & FAB & WHO & $\begin{array}{c}\text { WBC } \\
\mathbf{x} 109 / L\end{array}$ & PB & BM & Karyotype & $\begin{array}{c}\text { Molecular Defects } \\
\text { (Mutations) }\end{array}$ \\
\hline $1 *$ & $\mathrm{~F}$ & 32 & M1 & AML with t( $9 ; 11)$ & 0.4 & $80 \%$ & $73 \%$ & $46, \mathrm{XX}, \mathrm{t}(9 ; 11)$ & MLL1-AF9 \\
\hline 2 & $\mathrm{M}$ & 61 & M5 & AML monoblastic & 35.1 & $33 \%$ & $72 \%$ & $46, \mathrm{XY}, \mathrm{t}(11 ; 17)$ & MLL1-MSF \\
\hline 3 & M & 65 & M5 & AML with $\mathrm{t}(9 ; 11) / \mathrm{NPM} 1 \mathrm{~m}$ & 94.8 & $6 \%$ & $90 \%$ & $47, \mathrm{XY}, \mathrm{t}(9 ; 11),+8$ & $\begin{array}{c}\text { MLL1-AF9, } \\
\text { FLT3m, NPM1m }\end{array}$ \\
\hline $4^{\Delta}$ & M & 80 & M4 & AML with mutated NPM1 & 198.5 & $25 \%$ & $52 \%$ & $46, X Y$ & $\begin{array}{c}\text { FLT3m, } \\
\text { KIT D816V, NPM1m }\end{array}$ \\
\hline 5 & M & 54 & M1 & AML with NPM1m & 361.5 & $95 \%$ & $92 \%$ & $46, X Y$ & FLT3m, NPM1m \\
\hline 6 & $\mathrm{~F}$ & 49 & M4 & AML myelomonocytic & 15.4 & $16 \%$ & $63 \%$ & $46, X X$ & $\begin{array}{c}\text { FLT3m, } \\
\text { NPM1m, CEBPAm }\end{array}$ \\
\hline 7 & M & 67 & M1 & AML with myelodysplasia & 74.6 & $95 \%$ & $84 \%$ & complex & - \\
\hline $8^{* \Delta}$ & $\mathrm{F}$ & 61 & M5 & AML with myelodysplasia & 82.1 & $77 \%$ & $74 \%$ & 46,XX,del12p,del20q & - \\
\hline 9 & $\mathrm{~F}$ & 39 & M5 & AML monoblastic & 37.7 & $65 \%$ & $94 \%$ & $47, \mathrm{XX}, \mathrm{t}(3 ; 11),+8$ & - \\
\hline $10^{\Delta}$ & $\mathrm{F}$ & 49 & M4 & AML with inv16 & 94.2 & $47 \%$ & $57 \%$ & 46,XX,inv16 & FLT3m \\
\hline $11^{\Delta}$ & M & 58 & M2 & AML with $\mathrm{t}(8 ; 21)$ & 100.0 & $60 \%$ & $58 \%$ & $46, \mathrm{XY}, \mathrm{t}(8 ; 21)$ & - \\
\hline 12 & $\mathrm{M}$ & 23 & M2 & AML with $\mathrm{t}(8 ; 21)$ & 13.7 & $52 \%$ & $59 \%$ & $45, X,-Y, t(8 ; 21)$ & - \\
\hline 13 & M & 68 & $\begin{array}{c}\text { RAEB } \\
-T\end{array}$ & AML with myelodysplasia & 3.5 & $0 \%$ & $20 \%$ & $46, X Y$ & - \\
\hline $14^{\Delta}$ & M & 21 & M1 & AML without maturation & 133.2 & $95 \%$ & $88 \%$ & $46, X Y, \operatorname{add}(17 p)$ & - \\
\hline $15^{* \Delta}$ & $M$ & 49 & sec. & AML with myelodysplasia & 89.7 & $85 \%$ & n.t. & $46, X Y$ & - \\
\hline $16^{* \Delta}$ & M & 68 & M6a & Acute erythroid leukemia & 6.1 & $93 \%$ & $93 \%$ & n.t. & - \\
\hline $17 *$ & $\mathrm{M}$ & 44 & M4 & AML myelomonocytic & 90.2 & $91 \%$ & $92 \%$ & complex & - \\
\hline 18 & $\mathrm{~F}$ & 41 & M4 & AML myelomonocytic & 2.8 & $51 \%$ & $72 \%$ & $46, X X$ & - \\
\hline 19 & $\mathrm{~F}$ & 72 & M4 & Therapy-related AML & 93.2 & $62 \%$ & $74 \%$ & $46, X X$ & FLT3m, NPM1m \\
\hline 20 & $\mathrm{~F}$ & 52 & M1 & AML with mutated NPM1 & 64.1 & $88 \%$ & $80 \%$ & $46, X X$ & NPM1m \\
\hline $21^{* \Delta}$ & $\mathrm{F}$ & 73 & M1 & AML without maturation & 75.6 & $73 \%$ & $84 \%$ & $46, \mathrm{XX}, \mathrm{t}(3 ; ?)$ & FLT3m \\
\hline $22 *$ & $\mathrm{~F}$ & 65 & sec. & AML with myelodysplasia & 4.2 & $0 \%$ & $19 \%$ & $46, X X$ & FLT3m \\
\hline $23^{*}$ & M & 70 & sec. & AML with myelodysplasia & 1.9 & $25 \%$ & $15 \%$ & complex & - \\
\hline $24 *$ & $\mathrm{M}$ & 26 & M4 & AML myelomonocytic & 93.9 & $76 \%$ & $76 \%$ & $46, X Y$ & FLT3m \\
\hline $25^{*}$ & M & 71 & sec. & AML with myelodysplasia & 13.0 & $77 \%$ & $46 \%$ & $46, X Y$ & NPM1m, KIT D816V \\
\hline 26 & $\mathrm{~F}$ & 45 & M4 & AML with myelodysplasia & 66.8 & $53 \%$ & $66 \%$ & $46, X X$ & FLT3m \\
\hline $27 *$ & $\mathrm{M}$ & 72 & M4 & AML monocytic & 20.3 & $37 \%$ & $34 \%$ & $46, X Y,+11,-16$ & FLT3m \\
\hline 28 & M & 40 & M1 & AML with mutated NPM1 & 202.3 & $61 \%$ & $65 \%$ & $46, X Y$ & NPM1m, FLT3m \\
\hline 29 & $\mathrm{M}$ & 75 & sec. & AML with myelodysplasia & 18.8 & $29 \%$ & $21 \%$ & $47, \mathrm{XY},+\mathrm{mar}$ & JAK2 V617F, FLT3m \\
\hline 30 & $\mathrm{~F}$ & 50 & M5 & AML with mutated NPM1 & 50.9 & $4 \%$ & $23 \%$ & $46, X X$ & NPM1m \\
\hline $31^{\Delta}$ & $\mathrm{F}$ & 65 & M4 & AML with myelodysplasia & 62.2 & $79 \%$ & $70 \%$ & complex & - \\
\hline $32 * \Delta$ & $\mathrm{F}$ & 54 & M1 & AML without maturation & 23.3 & $81 \%$ & n.t. & n.t. & - \\
\hline $33^{* \Delta}$ & $\mathrm{M}$ & 59 & sec. & AML with myelodysplasia & 34.3 & $26 \%$ & n.t. & $47, \mathrm{XY}, \operatorname{add}(3),+8$ & - \\
\hline $34^{4}$ & $\mathrm{~F}$ & 84 & M4 & AML myelomonocytic & 132.0 & $8 \%$ & $29 \%$ & $46, X X$ & - \\
\hline $35^{\Delta}$ & $\mathrm{F}$ & 85 & M1 & AML with myelodysplasia & 1.7 & $0 \%$ & $33 \%$ & $46, X X$, del5q & - \\
\hline $36^{\Delta}$ & M & 64 & M1 & AML with maturation & 53.5 & $94 \%$ & $84 \%$ & $46, X Y$ & - \\
\hline $37 * \Delta$ & $\mathrm{M}$ & 53 & M2 & AML with myelodysplasia & 2.8 & $16 \%$ & $37 \%$ & $45, X Y,-7$ & - \\
\hline
\end{tabular}

*These patients were analyzed at relapse or persistence of blasts. Abbreviations: WBC, white blood count; F, female; M, male; Yrs, years; FAB, FrenchAmerican-British cooperative study group; WHO, World Health Organization; PB, peripheral blood; BM, bone marrow; n.t., not tested; FLT3m, mutated FLT3; NPM1m, mutated NPM1; CEBPAm, mutated CEBPA. ${ }^{\Delta}$ These patients were purified for $\mathrm{CD} 34^{+} / \mathrm{CD} 38^{-}$and $\mathrm{CD} 34^{+} / \mathrm{CD}^{3} 8^{+}$subfractions by cell sorting. 
clinical implications. In addition, our data are the first to show that a drug combination consisting of a BET bromodomain inhibitor and ARA-C, can produce strong synergistic growth-inhibitory effects in AML cells.

Expression of BRD4 in AML stem- and progenitor cells was demonstrable by qPCR and by immunostaining. Both the CD34+/CD38- and the CD34+/CD38+ stemand progenitor cells contained BRD4 mRNA as well as the BRD4 protein in all categories of AML, including refractory or relapsing disease. In addition, all AML cell lines examined were found to express BRD4. An interesting observation was that normal CD34+ stem cells also expressed BRD4, with similar expression levels compared to LSC. In addition, myeloid progenitor cells and even mature granulocytic cells were found to express BRD4 in the normal BM. These data suggest that targeting of BRD4 may result in a decreased production of normal BM cells. Indeed, we were able to show that
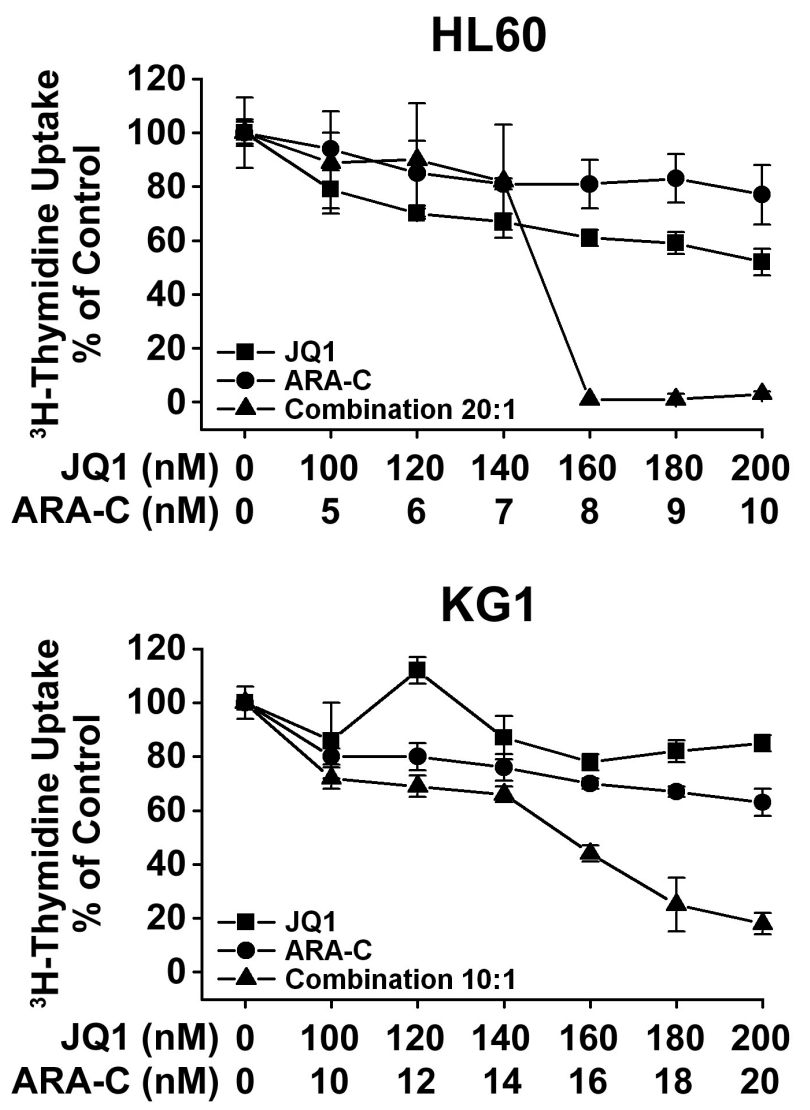

Figure 4: Synergistic growth-inhibitory effects of JQ1 and ARA-C on growth of AML cells. HL60 cells (upper panel) and KG1 cells (lower panel) were incubated in control medium or in medium containing various concentrations of JQ1, various concentrations of cytosine arabinoside (ARA-C), or a combination of both drugs at various concentrations at a fixed drug-ratio (20:1 for HL60 cells and 10:1 for KG1). Drugs were applied at $37^{\circ} \mathrm{C}$ for 48 hours. After incubation, uptake of ${ }^{3} \mathrm{H}$-thymidine was measured. Results are expressed as percent of medium control. Result of one typical experiment are shown. Almost the same results were obtained in 2 other independent experiments.
JQ1 inhibits the growth of normal BM cells in vitro. However, the concentrations required to fully block growth of normal BM cells were higher as that required to block proliferation of AML blasts. This difference may well provide a "pharmacological window" sufficient to introduce JQ1 or similar BET bromodomain inhibitors in clinical trials. In line with this assumption, JQ1 was not found to act as a myelosuppressive agent when applied in vivo in various mouse models [33].

BRD4 is a well known transcriptional regulator and chromatin modifier that plays a key role in cell cycle progression in normal and neoplastic cells [34-36]. More recent data suggest, that BRD4 exhibits atypical kinase activity and interacts with a number of nuclear and cytoplasmic interaction-partners such as SPA-1 [37,38]. In the present study, we were able to show that BRD4 is expressed in the cytoplasm and in nuclei of AML blasts and CD34+CD38-AML LSC. The prominent cytoplasmic location of BRD4 was somehow unexpected and suggests that BRD4 may fulfil as yet unknown biological functions in the cytoplasmic compartment of AML cells. An interesting observation was that BRD4 is also expressed in the cytoplasm and nuclei of normal bone marrow cells and highly enriched cord blood progenitor cells, although the expression levels were lower compared to AML cells. However, even in terminally differentiated non-dividing BM cells, BRD4 was found to be expressed in the cytoplasmic and nuclear compartment. These observations suggest that BRD4 may fulfil important functions in normal and neoplastic hematopoiesis, including immature myeloid stem- and progenitor cells and both the nuclear and cytoplamic compartment of these cells.

We have recently shown that the BRD4-blocking drug JQ1 induces growth inhibition and apoptosis in human and murine AML cells [33]. In the present study, we have extended these investigations and asked whether JQ1 would also block the growth and survival of leukemic cells in patients with relapsed or resistant AML. Indeed, our results show that JQ1 induces growth inhibition and apoptosis with reasonable IC50 values in primary AML cells in almost all patients examined, including patients with relapsed or resistant disease. This observation is of particular interest and may have clinical implications. In fact, these patients have a very poor prognosis, and novel drugs will be required to improve therapy. Whether indeed BRD4-targeting agents will be successful in the treatment of AML remains at present unknown. Based on our promising preclinical results, we recommend that BET bromodomain inhibitors should be evaluated for their efficacy in AML in forthcoming clinical trials.

As mentioned above, LSC are a major operational target of drug therapy [26-32,39]. In order to learn whether JQ1 would act anti-leukemic at the LSC level, we analyzed responses of CD34+CD38- cells and CD34+/ CD38+ cells to JQ1. In these experiments, JQ1 was found to induce apoptosis of CD34+CD38- and CD34+/CD38+ 
stem- and progenitor cells in all patients examined, including patients with relapsing or resistant AML. These data suggest that JQ1 may be capable of eradicating LSC, an assumption that needs to be confirmed in further preclinical and clinical studies.

Many of the novel anti-leukemic drugs used to treat refractory AML are applied in combination with other antiAML agents [40-42]. Therefore, it was of considerable interest to learn whether JQ1 would cooperate or even synergize with established chemotherapeutics when applied on AML cells. In the present study, we were able to show that JQ1 and ARA-C produce clear synergistic effects when used in combination to treat AML cells. This observation is of clinical importance and would be in favor of novel treatment concepts combining JQ1 or similar BRD4 inhibitors and ARA-C in patients with relapsing or refractory AML in clinical trials.

In conclusion, we have identified BRD4 as a novel drug target expressed in AML cells including AML LSC, and that JQ1 is an effective agent capable of blocking growth of AML cells and LSC through BRD4 inhibition. These observations may have clinical implications, as BRD4 blockers like JQ1 and similar agents may soon be applied in clinical trials to treat AML. Whether these drugs will improve therapy in relapsed or resistant AML remains to be determined.

\section{PATIENTS AND METHODS}

\section{Patients and isolation of AML cells}

A total number of 37 patients with AML (females, $\mathrm{n}=16$; males, $\mathrm{n}=21$ ) were examined. The median age was 59 years (range: $21-85$ years). Diagnoses were established according to the proposal of the French-AmericanBritish (FAB) cooperative study group $[43,44]$ and the classification of the World Health organization (WHO) [45]. Of the 37 patients, 23 had freshly diagnosed AML, and 14 suffered from refractory or relapsed AML. The patients' characteristics are shown in Table 3. For control purpose we examined bone marrow (BM) cells obtained from one patient with Non-Hodgkin's lymphoma without $\mathrm{BM}$ involvement, one with idiopathic cytopenia, and one with chronic myeloid leukemia (CML) in major molecular remission. Informed consent was obtained prior to BM puncture in each case. The study was approved by the Institutional Review Board (Ethics Committee) of the Medical University of Vienna. Mononuclear cells (MNC) were prepared using Ficoll and stored in liquid nitrogen until used or were used as freshly prepared MNC. After thawing, the viability of AML cells ranged from $75 \%$ to $99 \%$ as assessed by trypan blue exclusion.

\section{Cell lines}

AML cell lines used in this study were HL60, U937, KG1, MV4-11, and MOLM-13 (all from the German Collection of Microorganisms and Cell Cultures, Braunschweig, Germany). Cell lines were maintained in RPMI 1640 medium supplemented with $10 \%$ fetal calf serum (FCS; PAA laboratories, Pasching, Austria) at 5\% $\mathrm{CO}_{2}$ and $37^{\circ} \mathrm{C}$.

\section{Immunocytochemistry (ICC) and immuno- histochemistry (IHC)}

To confirm expression of BRD4 in leukemic cells, ICC and IHC were performed according to published protocols [46-48]. ICC was performed on AML cell lines (U937, HL-60, KG-1，MV4-11, MOLM-13), primary AML MNC, and sorted CD34+/CD38- AML LSC. Cells were spun on cytospin slides and incubated with a polyclonal rabbit anti-human BRD4 antibody (SigmaAldrich, St.Louis, MO; work dilution 1:100) for 20 hours. Cells were then washed and incubated with biotinylated goat-anti-rabbit $\operatorname{IgG}$ for 30 minutes. As chromogen, alkaline phosphatase complex (Biocare, Walnut Creek, CA) was used. Antibody-reactivity was made visible by Neofuchsin (Nichirei, Tokyo, Japan). In control experiments, the anti-BRD4 antibody was preincubated with control buffer or a BRD4-specific blocking peptide (Bethyl Laboratories, Montgomery, TX) for 1 hour before ICC or IHC were carried out.

IHC was performed on sections prepared from paraffin-embedded, formalin-fixed BM biopsy specimens (AML, $\mathrm{n}=13$; normal/reactive BM: $\mathrm{n}=6$ ) using the indirect immunoperoxidase staining technique as reported [46-48]. Prior to staining, sections were pretreated by microwave oven. Endogenous peroxidase was blocked by methanol/ $\mathrm{H}_{2} \mathrm{O}_{2}$. Slides were incubated with anti-BRD4 antibody (Sigma-Aldrich, work dilution: $1: 50 ; \mathrm{pH} 7.5$ ) at $4^{\circ} \mathrm{C}$ for 20 hours. Then, slides were washed and incubated with biotinylated anti-mouse IgG (Vector, Burlingame, CA) for 30 minutes, washed, and then exposed to Vectastain $\mathrm{ABC}$ KIT for 30 minutes. 3-amino-9-ethylcarbazole (AEC, Sigma) was used as chromogen. All slides were counterstained in Mayer's Hemalaun.

\section{Evaluation of proliferation by measuring ${ }^{3} \mathrm{H}$-thymidine uptake}

Primary cells (MNC) were cultured in 96-well microtiter plates (TPP, Trasadingen, Switzerland) (5$10 \times 10^{4}$ cells/well) in RPMI 1640 medium (PAA laboratories) plus $10 \% \mathrm{FCS}$ in the absence or presence of JQ1 $(10-5,000 \mathrm{nM})$ at $37^{\circ} \mathrm{C}\left(5 \% \mathrm{CO}_{2}\right)$. After 48 hours, $0.5 \mu \mathrm{Ci}{ }^{3} \mathrm{H}$-thymidine was added (16 hours). Cells were 
then harvested on filter membranes in a Filtermate 196 harvester (Packard Bioscience, Meriden, CT). Filters were air-dried, and the bound radioactivity was measured in a B-counter (Top-Count NXT, Packard Bioscience). All experiments were performed in triplicates. Proliferation was calculated as percent of medium control, and the inhibitory effects of JQ1 were expressed as $\mathrm{IC}_{50}$ values. In a separate set of experiments, AML cell lines (KG-1, HL60) were incubated in various concentrations of JQ1, various concentrations of ARA-C, or a combination of both drugs at fixed ratio of drug-concentrations.

\section{Flow cytometric evaluation of apoptosis in AML cells}

Primary AML cells $(n=9)$ were incubated in RPMI 1640 medium and $10 \%$ FCS in the absence or presence of various concentrations of JQ1 (10-5,000 nM) at $37^{\circ} \mathrm{C}$ $\left(5 \% \mathrm{CO}_{2}\right)$ for 48 hours. Thereafter, cells were subjected to flow cytometry experiments following published protocols [48-51]. Apoptosis was measured by combined Annexin-V/propidium-iodide staining and caspasestaining. Before being stained with rabbit anti-human monoclonal antibody (mAb) C92-605 (Becton Dickinson Biosciences) directed against active caspase 3, cells were fixed in paraformaldehyde $(2 \%)$ and permeabilized in methanol at $-20^{\circ} \mathrm{C}$ (15 minutes). Then, cells were washed and analyzed on a FACSCalibur (Becton Dickinson Biosciences). Apoptosis was expressed as percentage of active caspase 3-positive cells.

To study apoptosis in stem- and progenitor cells, $\mathrm{CD} 45^{+} / \mathrm{CD} 34^{+} / \mathrm{CD} 38^{+} \mathrm{BM}$ progenitor cells and $\mathrm{CD} 45^{+} /$ $\mathrm{CD} 4^{+} / \mathrm{CD} 38^{-} \mathrm{BM}$ stem cells were examined for apoptosis by combined staining for surface antigens, 4',6-diamidino2-phenylindole (DAPI; Invitrogen, Carlsbad, CA) and Annexin-V-FITC (eBioscience, San Diego, CA) as described [51]. Apoptosis was expressed as percent of Annexin-V+ cells after gating for DAPI-negative cells (early apoptotic cells). The mAb used to identify stemand progenitor cells were phycoerythrin-labeled CD34 mAb 581, the allophycocyanin-labeled CD38 mAb HIT2, and the peridinin chlorophyll protein-labeled CD45 $\mathrm{mAb}$ 2D1 (all from BD Biosciences, San José, CA).

\section{Purification of $\mathrm{CD34}+/ \mathrm{CD} 38+$ cells and $\mathrm{CD34}+/$ CD38- cells by cell-sorting}

In 15 patients with AML (patients \#4, \#8, \#10, \#11, \#14, \#15, \#16, \#21, \#31, \#32, \#33, \#34, \#35, \#36, \#37 in Table 3), CD $34^{+} / \mathrm{CD} 38^{-}$stem cells and $\mathrm{CD} 34^{+} / \mathrm{CD} 38^{+}$ progenitor cells were highly enriched by $\mathrm{mAb}$ and cell sorting essentially as described $[50,51]$. The purity of the sorted cells amounted to $>98 \%$.

\section{Reverse transcriptase PCR (RT-PCR) and quantitative PCR (qPCR)}

PCR experiments were performed on RNA from AML cell lines, unfractionated AML cells, sorted CD34 ${ }^{+}$/ $\mathrm{CD} 8^{+}$and $\mathrm{CD} 4^{+} / \mathrm{CD} 38^{-}$AML cells $(\mathrm{n}=9)$ and sorted cord blood $\mathrm{CD} 4^{+} / \mathrm{CD} 38^{+}$and $\mathrm{CD} 34^{+} / \mathrm{CD} 34^{-}$cells pooled from 3 donors. RNA was isolated using RNeasy MiniKit (Qiagen, Hilden, Germany). mRNA levels were quantified on a 7900HT Fast Real-Time PCR System from Applied Biosystems (Foster City, CA), using iTaq SYBR Green Supermix with ROX from Bio-Rad (Hercules, CA). $A B L$ was employed as a reference gene. Primers used in this study were: hu BRD4-forward:5 GCCCGCAAGCTCCA GGATGT-3' hu BRD4-reverse: 5 '-CCTCAGGCTCGTCCGGCATC-3`; hu ABL-forward: 5 '-TGTATGATTTTGTGGCCAGTGGAG-3`; and hu ABL-reverse: 5 '-GC CTAAGACCCGGAGCTTTTCA-3`.

\section{Statistical analysis}

Differences in growth and apoptosis in drugexposed cells were determined by appropriate statistical analysis, including the paired student's t test. Results were considered to be significantly different when the $p$ value was $<0.05$.

\section{ACKNOWLEDGEMENT}

We like to thank Günther Hofbauer and Andreas Spittler (both at the Cell Sorting Core Unit of the Medical University of Vienna) for excellent technical assistance.

C.R.V. is a consultant for Tensha Therapeutics. J.E.B. and the Dana-Farber Cancer Institute have founded Tensha Therapeutics to translate drug-like inhibitors of BET bromodomains as cancer therapeutic agents. The other authors declare no conflicts of interest.

\section{Support:}

This study was supported by a Cancer Stem Cell Research Grant from the Medical University of Vienna. C.R.V. is supported by a Burroughs-Wellcome Fund Career Award for Medical Scientists.

\section{REFERENCE}

1. Baldus CD, Mrózek K, Marcucci G, Bloomfield CD. Clinical outcome of de novo acute myeloid leukaemia patients with normal cytogenetics is affected by molecular genetic alterations: a concise review. $\mathrm{Br} \mathrm{J}$ Haematol. 2007; 137:387-400.

2. Neubauer A, Maharry K, Mrózek K, Thiede C, Marcucci G, Paschka $\mathrm{P}$, et al. Patients with acute myeloid leukemia and 
RAS mutations benefit most from postremission high-dose cytarabine: a Cancer and Leukemia Group B study. J Clin Oncol. 2008;26:4603-4609.

3. Schlenk RF, Döhner K. Impact of new prognostic markers in treatment decisions in acute myeloid leukemia. Curr Opin Hematol. 2009;16:98-104.

4. Kornblau SM, Tibes R, Qiu Y, Chen W, Kantarjian HM, Andreeff M, et al. Functional proteomic profiling of AML predicts response and survival. Blood. 2009;113:154-164.

5. Marcucci G, Haferlach T, Döhner H. Molecular genetics of adult acute myeloid leukemia: prognostic and therapeutic implications. J Clin Oncol. 2011;29:475-486.

6. Smith ML, Hills RK, Grimwade D. Independent prognostic variables in acute myeloid leukaemia. Blood Rev. 2011;25:39-51.

7. Schmid C, Kolb HJ. Allogeneic stem cell transplantation in the management of acute myeloid leukemia. Med Klin. 2007;102:317-323.

8. Meijer E, Cornelissen JJ. Allogeneic stem cell transplantation in acute myeloid leukemia in first or subsequent remission: weighing prognostic markers predicting relapse and risk factors for non-relapse mortality. Semin Oncol. 2008;35:449-457.

9. Ravandi F, Talpaz M, Kantarjian H, Estrov Z. Cellular signalling pathways: new targets in leukaemia therapy. Br J Haematol. 2002;116:57-57.

10. Stirewalt DL, Meshinchi S, Radich JP. Molecular targets in acute myelogenous leukemia. Blood Rev. 2003;17:15-23.

11. Stone RM. Novel therapeutic agents in acute myeloid leukemia. Exp Hematol. 2007;35:S163-S166.

12. Haferlach T. Molecular genetic pathways as therapeutic targets in acute myeloid leukemia. Hematology Am Soc Hematol Educ Program. 2008:400-411.

13. Martelli AM, Evangelisti C, Chiarini F, McCubrey JA. The phosphatidylinositol 3-kinase/Akt/mTOR signaling network as a therapeutic target in acute myelogenous leukemia patients. Oncotarget. 2010;1:89-103.

14. Lapidot T, Sirard C, Vormoor J, Murdoch B, Hoang T, Caceres-Cortes J, Minden M, Paterson B, Caligiuri MA, Dick JE. A cell initiating human acute myeloid leukaemia after transplantation into SCID mice. Nature. 1994;367:645648.

15. Bonnet D, Dick JE. Human acute myeloid leukemia is organized as a hierarchy that originates from a primitive hematopoietic cell. Nat Med. 1997;3:730-737.

16. Hope KJ, Jin L, Dick JE. Acute myeloid leukemia originates from a hierarchy of leukemic stem cell classes that differ in self-renewal capacity. Nat Immunol. 2004;5:738-743.

17. Chomel JC, Turhan AG. Chronic myeloid leukemia stem cells in the era of targeted therapies: resistance, persistence and long-term dormancy. Oncotarget. 2011;2:713-727

18. Vicente-Dueñas C, Barajas-Diego M, Romero-Camarero I, González-Herrero I, Flores T, Sánchez-García I. Essential role for telomerase in chronic myeloid leukemia induced by
BCR-ABL in mice. Oncotarget. 2012;3:261-266.

19. Jordan CT, Upchurch D, Szilvassy SJ et al. The interleukin-3 receptor alpha chain is a unique marker for human acute myelogenous leukemia stem cells. Leukemia. 2000;14:1777-1784.

20. Hosen N, Park CY, Tatsumi N et al. CD96 is a leukemic stem cell-specific marker in human acute myeloid leukemia. Proc Natl Acad Sci (USA). 2007;104:11008-11013.

21. Sarry JE, Murphy K, Perry R et al. Human acute myelogenous leukemia stem cells are rare and heterogeneous when assayed in NOD/SCID/IL2Rgammacdeficient mice. J Clin Invest. 2011;121:384-395.

22. Taussig DC, Miraki-Moud F, Anjos-Afonso F, Pearce DJ, Allen K, Ridler C, Lillington D, Oakervee H, Cavenagh J, Agrawal SG, Lister TA, Gribben JG, Bonnet D. Anti-CD38 antibody-mediated clearance of human repopulating cells masks the heterogeneity of leukemia-initiating cells. Blood. 2008; 112:568-575.

23. Taussig DC, Vargaftig J, Miraki-Moud F, Griessinger E, Sharrock K, Luke T, Lillington D, Oakervee H, Cavenagh J, Agrawal SG, Lister TA, Gribben JG, Bonnet D. Leukemiainitiating cells from some acute myeloid leukemia patients with mutated nucleophosmin reside in the CD34(-) fraction. Blood. 2010;115:1976-1984.

24. Pearce DJ, Taussig D, Zibara K et al. AML engraftment in the NOD/SCID assay reflects the outcome of AML: implications for our understanding of the heterogeneity of AML. Blood. 2006;107:1166-1173.

25. Eppert K, Takenaka K, Lechman ER et al. Stem cell gene expression programs influence clinical outcome in human leukemia. Nat Med. 2011;17:1086-1093.

26. Guzman ML, Jordan CT. Considerations for targeting malignant stem cells in leukemia. Cancer Control. 2004;11:97-104.

27. Sperr WR, Hauswirth AW, Florian S, Ohler L, Geissler K, Valent P. Human leukaemic stem cells: a novel target of therapy. Eur J Clin Invest. 2004;34:S31-S40.

28. Elrick LJ, Jorgensen HG, Mountford JC, Holyoake TL. Punish the parent not the progeny. Blood. 2005;105:18621866.

29. Krause DS, Van Etten RA. Right on target: eradicating leukemic stem cells. Trends Mol Med. 2007;13:470-481.

30. Essers MA, Trumpp A. Targeting leukemic stem cells by breaking their dormancy. Mol Oncol. 2010;4:443-450.

31. Krause A, Luciana M, Krause F, Rego EM. Targeting the acute myeloid leukemia stem cells. Anticancer Agents Med Chem. 2010;10:104-110.

32. Valent P. Targeting of leukemia-initiating cells to develop curative drug therapies: straightforward but nontrivial concept. Curr Cancer Drug Targets. 2011;11:56-71.

33. Zuber J, Shi J, Wang E, Rappaport AR, Herrmann H, Sison EA, et al. RNAi screen identifies Brd4 as a therapeutic target in acute myeloid leukaemia. Nature. 2011;478:524528. 
34. Wu SY, Chiang CM. The double bromodomain-containing chromatin adaptor Brd4 and transcriptional regulation. J Biol Chem. 2007;282:13141-13145.

35. Dey A, Nishiyama A, Karpova T, McNally J, Ozato K. Brd4 marks select genes on mitotic chromatin and directs postmitotic transcription. Mol Biol Cell. 2009;20:48994909.

36. Dawson MA, Kouzarides T, Huntly BJ. Targeting epigenetic readers in cancer. N Engl J Med. 2012;367:647657.

37. Farina A, Hattori M, Qin J, Nakatani Y, Minato N, Ozato $\mathrm{K}$. Bromodomain protein Brd4 binds to GTPase-activating SPA-1, modulating its activity and subcellular localization. Mol Cell Biol. 2004;24:9059-9069.

38. Devaiah BN, Lewis BA, Cherman N, Hewitt MC, Albrecht BK, Robey PG, Ozato K, Sims RJ 3rd, Singer DS. BRD4 is an atypical kinase that phosphorylates serine 2 of the RNA polymerase II carboxy-terminal domain. Proc Natl Acad Sci (USA). 2012;109:6927-6932.

39. Valent P, Bonnet D, De Maria R, Lapidot T, Copland M, Melo JV, Chomienne C, Ishikawa F, Schuringa JJ, Stassi G, Huntly B, Herrmann H, Soulier J, Roesch A, Schuurhuis GJ, Wöhrer S, et al. Cancer stem cell definitions and terminology: the devil is in the details. Nat Rev Cancer. 2012;12:767-775.

40. Fathi AT, Grant S, Karp JE. Exploiting cellular pathways to develop new treatment strategies for AML. Cancer Treat Rev. 2010;36:142-150.

41. Tallman MS. Novel therapeutic strategies for AML in 2012. Hematology. 2012;17:S43-S46.

42. Daver N, Cortes J. Molecular targeted therapy in acute myeloid leukemia. Hematology. 2012;17:S59-S62.

43. Bennett JM, Catovsky D, Daniel MT, et al. Proposals for the classification of the acute leukaemias. FrenchAmerican-British (FAB) co-operative group. Br J Haematol. 1976;33:451-458.

44. Bennett JM, Catovsky D, Daniel MT, et al. Proposed revised criteria for the classification of acute myeloid leukemia. A report of the French-American-British Cooperative Group. Ann Intern Med 1985;103:620-625.

45. Vardiman JW, Thiele J, Arber DA, Brunning RD, Borowitz MJ, Porwit A, Harris NL, Le Beau MM, HellstromLindberg E, Tefferi A, Bloomfield CD. The 2008 revision of the WHO classification of myeloid neoplasms and acute leukemia: rationale and important changes. Blood. 2009;114:937-951.

46. Baumgartner C, Cerny-Reiterer S, Sonneck K, Mayerhofer M, Gleixner KV, Fritz R, Kerenyi M, Boudot C, Gouilleux F, Kornfeld JW, Sillaber C, Moriggl R, Valent P. Expression of activated STAT5 in neoplastic mast cells in systemic mastocytosis: subcellular distribution and role of the transforming oncoprotein KIT D816V. Am J Pathol. 2009; 175:2416-2429.

47. Peter B, Gleixner KV, Cerny-Reiterer S, et al. Polo- like kinase-1 as a novel target in neoplastic mast cells: demonstration of growth-inhibitory effects of small interfering RNA and the Polo-like kinase-1 targeting drug BI 2536. Haematologica. 2011;96:672-680.

48. Gleixner KV, Mayerhofer M, Cerny-Reiterer S, et al. KITD816V-independent oncogenic signaling in neoplastic cells in systemic mastocytosis: role of Lyn and Btk activation and disruption by dasatinib and bosutinib. Blood. 2011;118:1885-1898.

49. Florian S, Sonneck K, Hauswirth AW, et al. Detection of molecular targets on the surface of CD34+/CD38-- stem cells in various myeloid malignancies. Leuk Lymphoma. 2006;47:207-222.

50. Hauswirth AW, Florian S, Printz D, et al. Expression of the target receptor CD33 in CD34+/CD38-/CD123+ AML stem cells. Eur J Clin Invest. 2007;37:73-82.

51. Herrmann H, Kneidinger M, Cerny-Reiterer S, Rulicke T, Willmann M, Gleixner KV, Blatt K, Hormann G, Peter B, Samorapoompichit P, Pickl W, Bharate GY, Mayerhofer M, Sperr WR, Maeda H, Valent P. The Hsp32 inhibitors SMAZnPP and PEG-ZnPP exert major growth-inhibitory effects on $\mathrm{CD} 34+/ \mathrm{CD} 38+$ and CD34+/CD38- AML progenitor cells. Curr Cancer Drug Targets. 2012;12:51-63. 